\title{
Toxoplasmosis, leptospirosis, and brucellosis seroepidemiology in veterinary medical students and their relation with unique health
}

\author{
Soroepidemiologia da toxoplasmose, leptospirose e brucelose em \\ acadêmicos de medicina veterinária e sua relação com a saúde única
}

\author{
Marília Clazer; Graziela Vendrame Rodrigues ${ }^{1}$; Bruna Paula Martins Ferreira ${ }^{1}$; \\ Melissa Marchi Zaniolo ${ }^{1}$; Nelton Anderson Bespalez Corrêa ${ }^{3}$; \\ Maíra Salomão Fortes ${ }^{1}$; Italmar Teodorico Navarro ${ }^{4}$; Roberta Torres Chiderolli ${ }^{5}$; \\ Julio Cesar de Freitas ${ }^{4}$; Daniela Dib Gonçalves ${ }^{2 *}$
}

\begin{abstract}
Toxoplasmosis, leptospirosis, and brucellosis are global zoonoses, with humans as accidental participants in their transmission cycles. The can also be considered occupational diseases, because certain professionals are at greater risk of contact and infection by such zoonoses. These three diseases have different epidemiological characteristics because of the distinct environmental, social, cultural, and economic conditions where these pathogens circulate. Because of the importance of these diseases and their associations with specific occupations, we performed a seroepidemiological survey of Toxoplasma, Leptospira, and Brucella antibodies, with an analysis of the association between positive serum and certain occupational and environmental variables, in students of a veterinary medicine course $\left(1^{\text {st }}, 2^{\text {nd }}\right.$, $3^{\text {rd }}, 4^{\text {th }}$, and $5^{\text {th }}$ year) in a university in the northwestern region in the state of Paraná, Brazil. From May to November 2014, blood samples were collected from 157 volunteers by professionals trained in nursing and biomedicine from the same university as the veterinary students. At the time of blood collection, the students did not present any clinical signs of the three diseases of interest. To detect antiToxoplasma gondii, anti-Leptospira spp., and anti-Brucella antibodies, indirect immunofluorescence test (IIF), microscopic agglutination test (MAT), fast agglutination test (a screening test), and enzymelinked immunosorbent assay (ELISA) were performed. To determine variables associated with these infections, the students were interviewed to complete an epidemiological questionnaire with environmental, behavioral, and occupational information. The associations between these variables and infections were assess by chi-square or Fischer's exact tests, with a 5\% significance level $(\alpha)$. Of the 157 serum samples analyzed, $29.29 \%$ reacted to Toxoplasma antigens, with titers ranging from 16 to 4096 by IIF, $1.27 \%$ to Leptospira antigens, with titers ranging from 100 to 800 by MAT using Hardjo and Wolffi serovars, and $0.63 \%$ to Brucella antigens by ELISA; however, no variables were found to be associated with infection with any of these pathogens. The results of this study show that one-third of the students in the veterinary medicine course were exposed to Toxoplasma gondii, Leptospira spp., and Brucella spp. at some stage in their lives; however, it is not possible to determine whether these infections were acquired at the university, because no associations between occupational risk variables
\end{abstract}

\footnotetext{
${ }^{1}$ Discentes, Programa de Pós-Graduação em Ciência Animal com Ênfase em Produtos Bioativos, Universidade Paranaense, UNIPAR, Umuarama, PR, Brasil. E-mail: mariliaclazer@bol.com.br; grazielavr@hotmail.com; bp_ferreira@hotmail.com; melissaz.vet@gmail.com; maira_salomao@yahoo.com.br

2 Prof ${ }^{\mathrm{a}} \mathrm{Dr}^{\mathrm{a}}$, Programa de Pós-Graduação em Ciência Animal com Ênfase em Produtos Bioativos, UNIPAR, Umuarama, PR, Brasil. E-mail: danieladib@prof.unipar.br

3 Prof. Me., Curso de Graduação de Farmácia, UNIPAR, Umuarama, PR, Brasil. E-mail: nelton@prof.unipar.br

${ }^{4}$ Profs. Drs., Programa de Pós-Graduação em Ciência Animal, Universidade Estadual de Londrina, UEL, Londrina, PR, Brasil. E-mail: italmar@uel.br; freitasj@uel.br

${ }^{5}$ Discente, Programa de Pós-Graduação em Ciência Animal, UEL, Londrina, PR, Brasil. E-mail: robertaa_tc@hotmail.com

* Author for correspondence
} 
and these infections were found. An understanding of the transmission of each etiological agent and methods to prevent infection is important to maintain low prevalence levels of these zoonotic diseases during the veterinary medicine course and extra-curricular internships, when there is increased exposure to these pathogens.

Key words: Antibodies, Brucella spp. Occupational disease. Leptospira spp. Toxoplasma gondii. Zoonosis.

\section{Resumo}

A toxoplasmose, leptospirose e a brucelose são zoonoses de ampla distribuição mundial, tendo o homem como participante acidental da sua cadeia epidemiológica, entretanto, podem se apresentar como doenças ocupacionais, em diferentes categorias profissionais, despertando grande preocupação, por estarem constantemente expostos ao risco de contato e contagio com essas zoonoses. Estas três enfermidades possuem características epidemiológicas distintas, como reflexo das diferenças ambientais, sociais, culturais e econômicas encontradas em cada localidade. Considerando a importâncias destas três enfermidades e sua relação com o aspecto ocupacional o objetivo deste trabalho foi realizar um levantamento soroepidemiológico para toxoplasmose, leptospirose e brucelose e identificar variáveis ocupacionais e ambientais relacionadas a estas três enfermidades em acadêmicos do curso de medicina veterinária de uma universidade da região noroeste do estado do Paraná, Brasil. No período de maio a novembro de 2014, foram coletadas amostras de sangue de forma voluntária de 157 acadêmicos do curso de Medicina Veterinária $\left(1^{\circ}, 2^{\circ}, 3^{\circ}, 4^{\circ}\right.$ e $5^{\circ}$ ano). A coleta de sangue foi realizada por profissionais habilitados da área de enfermagem e da biomedicina da respectiva universidade. No momento da coleta de sangue, os acadêmicos não apresentavam manifestação de qualquer sinal clínico das enfermidades deste estudo. Para detectar anticorpos anti-Toxoplasma gondii, anti-Leptospira spp. e anti-Brucella foram realizadas as técnicas de imunofluorescência indireta (RIFI), aglutinação microscópica (SAM), aglutinação rápida (triagem) e ensaio imunoenzimático (ELISA) respectivamente e para a detecção de variáveis associadas às infecções, os acadêmicos foram entrevistados, respondendo a um questionário epidemiológico com informações ambientais, comportamentais e ocupacionais relacionadas às enfermidades, sendo a associação verificada pelos testes de qui-quadrado ou exato de Fischer, adotandose um nível de significância $(\alpha)$ de 5\%. Das 157 amostras de soro analisadas 29,29\% foram reagentes para toxoplasmose com títulos variando de 16 a 4096 na IFI, 1,27\% para leptospirose com títulos de 100 e 800 na SAM com os sorovares Hardjo e Wolffi e $0,63 \%$ para brucelose no ELISA, entretanto não houve variáveis associadas a nenhuma infecção. Os resultados deste trabalho demostram que 1/3 dos acadêmicos do curso de medicina veterinária foram expostos ao Toxoplasma gondii, Leptospira spp. e Brucella spp. em algum momento de suas vidas, entretanto não podemos afirmar se esta infecção foi adquirida nas dependências da universidade já que não foi possível associar as variáveis de risco com as respectivas infecções. A conscientização desta população quanto às particularidades de cada agente etiológico e suas medidas de prevenção são fundamentais para manter as baixas taxas de prevalências das respectivas enfermidades zoonóticas durante o decorrer do curso de graduação e também quando da realização de estágios extra-curriculares, momento este de maior exposição aos diferentes agentes etiológicos.

Palavras-chave: Anticorpos. Brucella spp. Doença ocupacional. Leptospira spp. Toxoplasma gondii. Zoonose.

\section{Introduction}

Toxoplasmosis, leptospirosis, and brucellosis are zoonoses of great importance to public health, affecting humans who have direct or indirect contact with animals through various occupations (GONÇALVES et al., 2006).
Toxoplasmosis, one of the most common parasitic infections in the world, is caused by the protozoan Toxoplasma gondii, with domestic and/ or wild felines serving as infection reservoirs (FRENKEL et al., 1995). This zoonosis can result in severe disease in humans, particularly in its 
congenial form. It is of increasing importance in pregnant women and immune-suppressed patients who are infected for the first time (CAPOBIANGO et al., 2014; LANGONI et al., 2009).

Humans can be infected by ingestion of oocysts in contaminated water and food, by ingestion of bradyzoites in raw or undercooked meat, or by transplacental transmission of tachyzoites, transfusion of leukocytes, transplantation of organs, ingestion of non-pasteurized goat milk, or accidents in the laboratory (DUBEY et al., 2002; DUBEY, 2010). T. gondii infection is highly prevalent in humans in Brazil, with $50 \%$ of children and $80 \%$ of women in fertile age present antibodies against this protozoan (DUBEY et al., 2012).

Another very important zoonosis globally is leptospirosis, a contagious disease with endemic and seasonal transmission. It is transmitted directly or indirectly by as many as 250 bacterial species in the genus Leptospira, which can infect humans and various wild and/or domestic animal species (CONFALONIERI; DUTRA, 2014; FAINE et al., 1999). Humans are considered accidental and terminal hosts in the transmission chain of this disease; they can be infected by direct exposure to blood, urine, or tissue from infected animals or indirectly through water, mud, pasture soil, trough and stable surfaces, or food contaminated with the microorganism (FAINE et al., 1999).

Among the factors that favor persistence of Leptospira, its antigenic variability, relative degree of survival in environmental level with the absence of parasitism, and wide variety of susceptible vertebrates are particularly important. Rodents are the main reservoirs, sheltering Leptospira in kidneys and excreting the organisms alive in urine to the environment, contaminating water, soil, food, other animals, and even humans (FAINE et al., 1999).

Another frequent global zoonosis is brucellosis, caused by bacteria belonging to the genus Brucella, which are Gram-negative facultative intracellular microorganisms that do not form spores. A total of nine species (and their hosts) have been described, namely Brucella melitensis (goats), Brucella abortus (cattle), Brucella suis (pigs, reindeer), Brucella ovis (sheep), Brucella canis (dogs), Brucella neotomae lépida (Neotoma lepida, desert rodents), Brucella ceti (dolphins and whales), Brucella pinnipedialis (seals), and Brucella microti arvalis (Microtus arvalis, wild mice) (DIAS, 2012; GUIMARÃES, 2011).

Human infections may occur through direct exposure to an infected animal, including its tissues, blood, urine, vaginal or other excretions, or carcass, or through indirect exposure, including the ingestion of raw or undercooked meat, non-pasteurized milk, or dairy products originating from an infected animal (POESTER et al., 2009). Brucellosis is a global public health problem: it is underdiagnosed and underreported, with an estimated 25 cases for every diagnosed case (CARDOSO; COSTA, 2012). The prevalence of Brucella infections in humans is closely associated with the prevalence of the pathogen in animals, and, for this reason, in (BRASIL, 2001), the National Program for the Control and Eradication of Animal Brucellosis and Tuberculosis (Programa Nacional de Controle e Erradicação da Brucelose e da Tuberculose Animal, PNCEBT) was created by the Ministry of Agriculture, Livestock, and Food Supply (MAPA), with the purpose of reducing the prevalence of these infections in animals, and, consequently, in human beings (BRAZIL, 2001).

The three diseases of interest in this study are occupational; that is, humans can acquire the infection from their working environment through direct or indirect exposure to infected animals or contaminated animal products and by-products. Cases of these disease have been recognized in workers in slaughterhouses, dairy factory, and laboratories, in insemination and rural workers, in veterinarians, in other professionals working in the clandestine slaughtering of animals, vaccination of herds, and other occupations (GONÇALVES et al., 2006, 2013; GRESSLER et al., 2012; PELISSARI et al., 2011; RAMOS et al., 2008; SANTOS et al., 2007). 
Serological investigations of anti- $T$. gondii, antiLeptospira spp., and anti-B. abortus antibodies have already indicated risk factors in veterinary students in different regions of Brazil (LACERDA et al., 2000; LIMA, 2008; LANGONI et al., 2009). Owing to the importance of these three diseases and their association with occupation, we performed a seroepidemiological survey for Toxoplasma, Leptospira, and Brucella antibodies, as well as analyzed occupational and environmental variables related to infection with these organisms, in students in a veterinary medicine course in a university in the northwestern region in the state of Paraná, Brazil.

\section{Material e Methods}

\section{Study location and sample collection}

From May to November 2014, blood samples were collected from 157 student volunteers in a veterinary medicine course $\left(1^{\text {st }}, 2^{\text {nd }}, 3^{\text {rd }}, 4^{\text {th }}\right.$, and $5^{\text {th }}$ year) from a university located in the northwestern region in the state of Paraná. Blood sampling was performed in an appropriate location at the university by a trained professional. At the time of blood collection, the students did not present any clinical signs of the diseases studied.

A total of 157 serum samples was collected, with $38(24.23 \%)$ belonging to students in the first year, $33(21.01 \%)$ to students in the second year, $35(22.29 \%)$ in the third year, $27(17.19 \%)$ in the fourth year, and $24(15.28 \%)$ in the fifth year; 74 $(47.14 \%)$ were from females and $83(52.86 \%)$ were from males.

\section{Serological diagnoses}

Each serum sample was divided into three aliquots of equal volume, stored in sterile flasks, and held at $-20^{\circ} \mathrm{C}$ for later serological examination.

To detect anti-Leptospira spp. antibodies, the serum samples were submitted to microscopic agglutination testing (MAT) (RYU, 1970) at the Laboratory of Leptospirosis in the Department of
Preventive Veterinary Medicine (DMVP) at the State University of Londrina (UEL), with 22 reference serovars, namely Australis, Bratislava, Autumnalis, Butembo, Fortbragg, Castellonis, Bataviae, Canicola, Whitcombi, Cinoptery, Grippothyphosa, Hebdomadis, Copenhageni, Icterohaemorrhagiae, Panama, Pomona, Pyrogenes, Hardjo, Wolffi, Shermani, Tarassovi, and Sentot. The samples were stored at $28^{\circ} \mathrm{C}$ for 5 to 10 days in modified EMJH (Difco, USA) medium (ALVES et al., 1996). Serum samples showing at least 50\% agglutination at 1:100 dilution were considered reactors and sera were two-fold serially diluted to determine the maximum positive dilution. The probable infecting serovar was considered the one associated with the highest agglutinating titer; those showing co-agglutination at the highest dilution were considered as only reagent to Leptospira spp. (BATISTA et al., 2005).

To detect anti-Brucella abortus antibodies, the serum samples were sent for a fast agglutination screening test at the Laboratory of Preventive Veterinary Medicine and Public Health at Universidade Paranaense (UNIPAR). They were tested using commercial kits prepared with $B$. abortus antigen (proteins and lipopolysaccharides) produced by Ebram Produtos Laboratoriais Ltd., São Paulo (SP). Samples showing agglutination were considered as reactors. To confirm these results, reactive samples were tested for $\operatorname{IgM}$ and $\operatorname{IgG}$ antibodies by enzyme-linked immunosorbent assay (ELISA) in a private laboratory, with results greater than 11.0 for both $\operatorname{IgM}$ and $\operatorname{IgG}$ considered positive. A serum sample was only considered positive when it was reaction in both serological tests.

To detect antibodies against T. gondii, an indirect immunofluorescence test (IIF) was performed according to methods described by Camargo (1974). The slides containing antigens (tachyzoites) of the RH strain were prepared in the Zoonosis and Public Health laboratory at DMVPUEL. The sera were four-fold diluted, starting at a titer of 1:16, with sera from humans known to be positive and negative for Toxoplasma used as controls. IIF slides were read under an epi- 
fluorescence microscope (Leica, DMLS) at 400× magnification. Samples showing fluorescence at a titer of 1:16 were considered positive.

\section{Questionnaire}

To determine variables associated with infection by each of the three pathogens, the study participants were interviewed to complete a questionnaire on environmental, behavioral, and occupational variables related to the diseases addressed in this study.

\section{Statistical analysis}

To determine the association between serological results the different variables, Fischer's exact test and chi-square tests were performed in Bioestat 5.0 (AYRES et al., 2007), with the significance level set at $5 \%$.

\section{Results}

Of 260 students in the Veterinary Medicine program, $157(60.38 \%)$ participated in the study voluntarily. Of these, 49 (31.21\%) were considered reactors to at least one of the three zoonotic diseases in this study (Table 1).

Of the 49 positive samples subjected to serological testing, 17 (34.69\%) samples were obtained from students in their first year, eight $(16.33 \%)$ from students in their second year, nine $(18.37 \%)$ from students in their third year, six (12.24\%) from students in their fourth year, and nine (18.36\%) from students in their fifth year. Of the seroreactive samples, $26(53.06 \%)$ were from female and 23 (46.93\%) from male students (Table 2).

For Toxoplasma, 46 (29.29\%, 46/157) samples were considered positive by IIF, presenting antibody titers ranging from 16 to 4096 (Table 3). No variable studied was considered statistically significantly associated with Toxoplasma infection (Tables 4 and 5).

For leptospirosis, two $(1.27 \%, 2 / 157)$ samples were considered positive by MAT, and antibodies against the following serovars were detected: Hardjo $(50 \%, 1 / 2)$, with a titer of 100 , and Wolffi $(50 \%, 1 / 2)$, with titer of 800 . Both sample were from male subjects. No variable studied was found to be statistically significantly associated with Leptospira infection (Tables 4 and 5).

Table 1. Results of indirect immunofluorescence (IIF) assay for Toxoplasma gondii, microscopic agglutination test (MAT) for Leptospira, and immunoenzymatic assay (ELISA) for Brucella antibodies by gender in 46 serum samples from students in a veterinary medicine course in a university located in the northwestern region in the state of Paraná, Brazil, 2014.

\begin{tabular}{cccc}
\hline Gender & & Antibody Frequency & \\
\hline & Indirect immunofluorescence & Microscopic seroagglutination & Immunoenzymatic assay \\
Female & assay (IIF) & test (MAT) & (ELISA) \\
Male & $26(56.53 \%)$ & -- & -- \\
\hline Total & $20(43.47 \%)$ & $02(1.27 \%)$ & $01(0.63 \%)$ \\
\hline
\end{tabular}


Table 2. Results of indirect immunofluorescence (IIF) for Toxoplasma gondii, microscopic seroagglutination test (MAT) for Leptospira, and immunoenzymatic assay (ELISA) for Brucella antibodies by university year $\left(1^{\text {st }}, 2^{\text {nd }}, 3^{\text {rd }}\right.$, $4^{\text {th }}$, and $5^{\text {th }}$ year) in 46 serum samples from students in a veterinary medicine course in a university located in the northwestern region in the state of Paraná, Brazil, 2014.

\begin{tabular}{cccc}
\hline University Year Frequency & & \\
\hline & $\begin{array}{c}\text { Indirect immunofluorescence } \\
\text { assay (IIF) }\end{array}$ & $\begin{array}{c}\text { Microscopic seroagglutination } \\
\text { test (MAT) }\end{array}$ & $\begin{array}{c}\text { Immunoenzymatic assay } \\
\text { (ELISA) }\end{array}$ \\
\hline $1^{\text {st }}$ year & $16(32.65 \%)$ & -- & $01(2.04 \%)$ \\
$2^{\text {nd }}$ year & $08(16.33 \%)$ & -- & -- \\
$3^{\text {rd }}$ year & $07(14.29 \%)$ & $02(4.08 \%)$ & -- \\
$4^{\text {th }}$ year & $06(12.24 \%)$ & -- & -- \\
$5^{\text {th }}$ year & $09(18.36 \%)$ & -- & -- \\
\hline Total & $46(93.88 \%)$ & $02(4.08 \%)$ & $01(2.04 \%)$ \\
\hline
\end{tabular}

Table 3. Frequency of specific antibody titers detected by indirect immunofluorescence assay (IIF) for Toxoplasma gondii in 46 serum samples from students in a veterinary medicine course in a university located in the northwestern region in the state of Paraná, Brazil, 2014.

\begin{tabular}{cccc}
\hline \multirow{2}{*}{ Antibody Titers } & \multicolumn{2}{c}{ Frequency } & Total (\%) \\
\cline { 2 - 3 } & Female & Male & $03(06.52 \%)$ \\
64 & 01 & 02 & $10(21.74 \%)$ \\
256 & 07 & 03 & $27(58.69 \%)$ \\
1024 & 15 & 12 & $05(10.87 \%)$ \\
4096 & 03 & 02 & $01(02.18 \%)$ \\
\hline Total & - & 01 & $46(100 \%)$ \\
\hline
\end{tabular}

Table 4. Result of the chi-square $\left(\Pi^{2}\right)$ testing of the association between specific variables and the presence of Toxoplasma gondii, Leptospira or Brucella antibodies in 157 serum samples from students in a veterinary medicine course in a university located in the northwestern region in the state of Paraná, Brazil, 2014.

\begin{tabular}{|c|c|c|c|}
\hline Variable & $\begin{array}{c}\text { Percent } \\
\text { Positive (\%) }\end{array}$ & P-value & OR $(95 \% \mathrm{CI})$ \\
\hline \multicolumn{4}{|c|}{ Toxoplasma gondii } \\
\hline \multicolumn{4}{|c|}{ Gender } \\
\hline Male & $20 / 46(43.48 \%)$ & & \\
\hline Female & $26 / 46(56.52 \%)$ & & \\
\hline \multicolumn{4}{|c|}{ Ingestion of raw meat } \\
\hline Yes & $33 / 46(71.74 \%)$ & \multirow{2}{*}{$0.201 * *$} & 1.623 \\
\hline No & $13 / 46(28.26 \%)$ & & $(0.770-3.420)$ \\
\hline \multicolumn{4}{|c|}{ Ingestion of raw non-sanitized vegetables } \\
\hline Yes & $45 / 46(97.83 \%)$ & \multirow{2}{*}{$0.111^{*}$} & 5.814 \\
\hline No & $1 / 46(2.17 \%)$ & & $(0.734-46.056)$ \\
\hline
\end{tabular}


continuation

Contact with cats during academic activities

Yes
No

Habit of sanitizing the hands after contact with animals

\begin{tabular}{|c|c|c|}
\hline Yes & $\begin{array}{c}44 / 46(95.65 \%) \\
2 / 46(4.35 \%)\end{array}$ & 0.586 \\
\hline
\end{tabular}

AIs aware of the transmission and prevention of $T$. gondii

Yes

$(86.96 \%)$

$0.952 * *$

1.032

No

$6 / 46(13.04 \%)$

$(0.371-2.869)$

Leptospira spp.

Gender

Male

Female

$2 / 2(100 \%)$

Presence of rodents at home

Yes

No

Habit of keeping the trash closed

Yes

No

Cleans the kennel

Yes

No

$38 / 46(82.61 \%)$

$0.520^{* *}$

1.337

$(0.550-3.249)$

$0.593 .146)$

Contact with domestic animals during academic activities

Yes

$2 / 2(100 \%)$

$1 / 2(50 \%)$

$1 / 2(50 \%)$

$1.000^{*}$

0.742

$1 / 2(50 \%)$

$1 / 2(50 \%)$

$0.567^{*}$

$(0.66-8.360)$

No

$1 / 2(50 \%)$

$1 / 2(50 \%)$

$0.579 *$

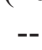

$1.000^{*}$

0.632

$(0.56-7.175)$

Is aware of the transmission and methods to prevent infection

with Leptospira

Yes

$2(100 \%)$

$1.000^{*}$

1.116

No

$--$

$(1.058-1.178)$

Brucella spp.

Gender

Male

Female

Frequent ingestion of raw milk/fresh cheese

Yes

No

Has vaccinated animals against brucellosis

Yes

No

$1 / 1(100 \%)$

$1.000^{*}$

Injured while administering this vaccine

Yes

No

$1 / 1(100 \%)$

1.000

Assisted in dystocia/fetotomia

Yes

No

$1 / 1(100 \%) \quad 1.000 *$

Is aware of the mode of transmission and methods to prevent infection with Brucella

$\begin{array}{lcc}\text { Yes } & 1 / 1(100 \%) & 1.000^{*} \\ \text { No } & -- & \end{array}$

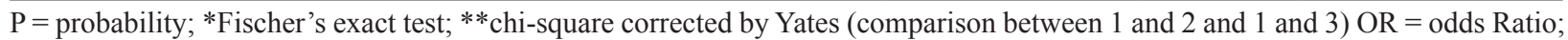
$\mathrm{CI}=$ confidence interval. 
Table 5. Result of chi-square $\left(\mathrm{P}^{2}\right)$ testing of the association between common variables and the presence of Toxoplasma gondii, Leptospira or Brucella antibodies in 157 serum samples from students in a veterinary medicine course in a university located in the northwestern region in the state of Paraná, Brazil, 2014.

\begin{tabular}{|c|c|c|c|}
\hline $\begin{array}{r}\text { Disease } \\
\text { Variable } \\
\end{array}$ & $\begin{array}{c}\text { Percent } \\
\text { Positive (\%) }\end{array}$ & P-value & OR $(95 \% \mathrm{CI})$ \\
\hline \multicolumn{4}{|c|}{$\begin{array}{l}\text { Use of personal protective equipment for clinical practice with } \\
\text { domestic animals }\end{array}$} \\
\hline Yes & $49 / 49(100 \%)$ & $0.353 * *$ & -- \\
\hline No & -- & & \\
\hline \multicolumn{4}{|c|}{$\begin{array}{l}\text { Use of personal protective equipment for handling of biologi- } \\
\text { cal materials (urine, feces, blood, semen) }\end{array}$} \\
\hline Yes & $49 / 49(100 \%)$ & \multirow{2}{*}{$0.353 * *$} & \multirow{2}{*}{--} \\
\hline No & -- & & \\
\hline \multicolumn{4}{|c|}{ Injured when collecting biological material } \\
\hline Yes & $10 / 49(20.41 \%)$ & \multirow{2}{*}{$0.850 * *$} & 0.925 \\
\hline No & $39 / 49(79.59 \%)$ & & $(0.414-2.069)$ \\
\hline \multicolumn{4}{|c|}{ Performed extracurricular internship } \\
\hline Yes & $21 / 49(42.86 \%)$ & \multirow{2}{*}{0.387} & 0.743 \\
\hline No & $28 / 49(57.14 \%)$ & & $(0.378-1.459)$ \\
\hline
\end{tabular}

$\mathrm{P}=$ probability; *Fischer's exact test; **chi-square corrected by Yates (comparison between 1 and 2 and 1 and 3 ) OR $=$ odds ratio; $\mathrm{CI}=$ confidence interval.

For brucellosis, two $(1.27 \%, 2 / 157)$ samples were considered positive by the screening test. However, only one sample $(0.63 \%, 1 / 157)$ was confirmed positive, presenting IgG and IgM levels of 20.1 and 18.5 , respectively. This sample was from a male subject. No variable studied was considered statistically significantly associated with Toxoplasma infection (Tables 4 and 5). However, students with positive sera reported frequent ingestion of raw meat and fresh cheese.

\section{Discussion}

The general prevalence of $T$. gondii, Leptospira, or Brucella antibodies in the students was $31.21 \%$, suggesting that these students were directly or indirectly exposed to $T$. gondii, Leptospira spp., or Brucella spp. at some stage in their lives.

The prevalence of $T$. gondii antibodies was 29.29\%. This was similar to results by Araújo et al. (2000) (30.34\%) and Lima (2008) (25.5\%), who surveyed veterinary medicine students in Campo Grande (Mato Grosso do Sul) and western
Paraná (PR), respectively. This can be explained by the vastness of Brazil, with social-cultural and behavioral differences in each region and climate, which directly affect the survival and infectiousness of the etiological agent, and, consequently, directly impact the epidemiology of toxoplasmosis in each study location (BITTENCOURT et al., 2012; CAETANO, 2013; COUTO et al., 2003)

The antibody titers detected by IIF in six (13.04\%) samples indicated that these infections were acute, because a dilution of greater than 1:1024 is generally considered evidence of a recent $T$. gondii infection. Goldsmith (1997) reported that IgM can be detected by IIF 1 or 2 weeks after infection, reaches a peak at 6 to 8 weeks, then declines.

T. gondii infection was not associated with any environmental, behavioral, or occupational variables in the survey. This result was similar to those found by Lima (2008) in western Paraná (PR) and Vicente et al. (2014) in Rio de Janeiro (RJ). Even though risk variables were not identified in this work, $82.60 \%$ of the reactors reported having contact with cats, $71.73 \%$ reported frequently 
ingesting raw or undercooked meat, and $97.82 \%$ reported ingesting raw unsanitized vegetables. With these frequencies, it is clear that an awareness of the biological cycle of $T$. gondii, including temperature, humidity, and oxygenation, correct use of a cat litter box, sanitation of vegetables, and avoiding raw or undercooked meats are extremely important for the prevention of human infection.

Although leptospirosis is also considered an occupational disease (GONÇALVES et al., 2013), the prevalence of this infection in humans is largely unknown. Many cases of human leptospirosis are not reported, with the infection being frequently confused with colds and influenza (FAINE et al., 1999). Therefore, it is important to study professionals in certain occupations to understand its epidemiology.

The prevalence of Leptospira antibodies was of $1.27 \%$. A higher prevalence $(30.40 \%)$ was detected by Lima (2008) in western Paraná (PR), and a lower prevalence $(0 \%)$ was reported by Langoni et al. (2009) in Botucatu (SP). These serological results might have been affected by the prevalence of Leptospira infections in animals in the respective locations and study periods. This low prevalence is similar to that reported in dogs and sheep in the same region as this study (DREER et al., 2013; OLIVEIRA, 2014). This can be explained by the fact that the northwestern region of the state of Paraná is located in a pedologic area, characterized by soil of medium to sandy texture $(70 \%)$ sand composition, in a region known as Caiuá Sandstone), leading to greater water permeability that may have limited survival of the microorganism, because humidity is need for it to survive, grow, and multiply (EMBRAPA, 1999; FAINE et al., 1999; OLIVEIRA, 2014). However, by MAT, one sample showed an antibody titer of 1:800, which, according to the Ministry of Health, is evidence of an acute infection (BRASIL, 1995).

No environmental, behavioral, and occupational variables were found to be associated with Leptospira infection. However, antibody against the Hardjo and Wolffi serovars in samples reactiveng to MAT suggests the possible involvement of the university students in an occupational relationship, since these two serovars are the ones most commonly detected in cattle, that are considered the main infection reservoirs (FAINE et al., 1999). Chronically infected and asymptomatic cattle can eliminate the bacteria through the urine for long periods of time, thus contributing to the persistence of infection focuses (GUIMARÃES et al., 1982). Therefore, the bovine species significantly contribute to the maintenance of infection in humans and in other animal species by direct exposure to urine, post-abortion uterine discharges, fetuses, placenta, uterine infections and/ or infected semen (ELLIS, 1994).

Brucellosis is a disease of global distribution, endemic in several regions in Brazil; however, it presents very different prevalences due to the territorial dimension and the characteristics specific of each region (LAGE et al., 2008; RIBEIRO et al., 2008).

The prevalence of brucellosis in veterinary medicine students is little known, since there are few studies performed on university students. On the other hand, in the occupational character, Mendonça (1997) in the city of Garanhus (Pernambuco) found $2.99 \%$ of individuals positive to B. abortus in workers from butcheries, cattle breeders and animal feeders. Higher results were found by Lacerda et al. (2000) in the northeastern region, where $10.17 \%$ seropositivity were observed in slaughterers in two slaughterhouses in the city of São Luis, Maranhão.

In this study, the prevalence of anti-Brucella spp antibodies in the university students was low, presenting a $0.63 \%$ rate, that is, only one sample was considered positive to this disease. This result is similar to the one found by Branco (2015), which detected a $0.86 \%$ prevalence in cows, but lower than the one in Dias et al. (2009) where the prevalence of bovine brucellosis was $1.70 \%$, both in the northwestern region of the state of Paraná (PR). 
The low prevalence detected in this study can be a reflection of the improvement of animal sanity in the bovine herd of the northwestern region in relation to the sanitary handling, as well as the awareness and adoption of practices demanded since 2001 by the National Plan for the Control and Eradication of Animal Brucellosis and Tuberculosis established by the Ministry of Agriculture, Livestock and Food Supply (MAPA) in Brazil.

Regarding antibody titers detected in ELISA, it is understood that the infection of the student is acute, since it presented IgM indexes above the cutoff point.

In this paper, it was not possible to associate the infection of university students with environmental, behavioral and occupational variables, although the student reported that he has the habit of ingesting raw or undercooked meat and fresh cheese in the epidemiological questionnaire. According to Paulin and Ferreira Neto (2008), eating habits is an indirect form of acquiring infection, such as: raw or undercooked animal products, raw milk or nonpasteurized dairy products (cheese, butter, yogurt, ice cream) originated from possibly infected animals.

The non-association of risk variables with the diseases in this study may have occurred due to the incomplete participation of the 260 students, or even by the low serological prevalences detected for the different diseases. A different result could have been found if all the students regularly enrolled in the course had taken part in this study, where only $1 / 3$ of the students voluntarily took part. This study is an opportunity to systematize and discuss conceptual, educational and sanitary aspects of professionals who are exposed to different etiological agents, aiming at improving their attributions regarding the health of the professional $\mathrm{x}$ animal health, leading to the most modern concept of Unique Health currently being discussed by professionals in different areas in the world.

It is important to emphasize that from the 49 (31.21\%) samples considered positive for the three diseases studied, 26 (53.06\%) were female students, which does not corroborate with Teixeira et al. (1998), who reported that the male gender is the most commonly infected, probably due to the highest exposure and professional/occupational activities they have, such as veterinaries, miners, farmers, slaughterhouse workers, public cleaning, animal handlers and fishermen, among other professions, since they are exposed to possibly infected animals or their byproducts (blood, urine, feces, placenta, tissues, mucus). This higher positivity related to the female gender may be due to change in the profile of freshmen in the Veterinary Medicine course.

Another important issue in this paper is that $100 \%$ of the students who took part in the survey reported using the PPEs (gloves, goggles, boots and overalls) during clinical service or the handling of biological material (blood, urine, feces, placenta, tissues, mucus), which could also have contributed to ensure the greater integrity of the students, animals and environment itself, since it found a low prevalence for toxoplasmosis, leptospirosis and brucellosis.

The results of this study indicate that there were $49(31.21 \%)$ students in the veterinary medicine course previously exposed to T. gondii, Leptospira spp. or Brucella spp. at some moment in their lives. However, it was not possible to determine whether these infections were acquired during their time at the university, because we found no association between positive serum and risk variables. An awareness of these etiological agents and methods to prevent infection is important to maintain these low prevalence levels throughout the veterinary medicine course and during extra-curricular internships, when there is greater risk of exposure to various pathogens.

Additional studies on veterinary medicine students and other professionals should be conducted to better understand One Health (human and animal) in the northwestern region in the state of Paraná. 


\section{Ethics Committee}

This project was submitted to the Ethics Committee on Research Involving Human Beings (CEPEH) at UNIPAR and Plataforma Brasil and was approved under protocol 443.790 on $01 /$ Nov/ 2013.

\section{Acknowledgments}

The authors would like to thank the students in the veterinary medicine course for their collaboration and UNIPAR and CAPES for the funding granted for this research.

\section{References}

ALVES, C. J.; VASCONCELLOS, S. A.; CAMARGO, C. R. A.; MORAIS, Z. M. Influência de fatores ambientais sobre a proporção de caprinos soro-reatores para Leptospirose em cinco centros de criação do Estado da Paraíba, Brasil. Biológico, São Paulo, v. 63, n. 2, p. 11-18, 1996.

ARAÚJO, F. R. A.; SARTI, E. E.; CROCCI, A. J.; SEABRA, V. M. S.; AMORIM, J. H.; CUSINATO, F. Q.; ARAÚJO, C. P.; CARVALHO, C. M. E. Anticorpos contra Toxoplasma gondii em estudantes de medicina veterinária de Campo Grande, MS, Brasil. Ciência Rural, Santa Maria, v. 30, n. 6, p. 1017-1019, 2000.

AYRES, M.; AYRES JÚNIOR, M.; AYRES, D. L.; SANTOS, A. A. S. BioEstat: aplicações estatísticas nas áreas das ciências biomédicas. Belém: Universidade Federal do Pará, 2007. 364 p.

BATISTA, C. S. A.; ALVES, C. J.; AZEVEDO, S. A.; VASCONCELLOS, Z. M.; MORAIS, I. J.; CLEMENTINO, F. A. L.; LIMA, F. S.; ARAÚJO NETO, J. O. Soroprevalência e fatores de risco para a leptospirose em cães de Campina Grande, Paraíba. Arquivo Brasileiro de Medicina Veterinária, Belo Horizonte, v. 57, n. 2, p. 179-185, 2005.

BITTENCOURT, L. H. F. B.; LOPES-MORI, F. M. R.; MITSUKA-BREGANÓ, R.; FREIRA, R. L.; PINTO, S. B.; NAVARRO, I. T. Soroepidemiologia da toxoplasmose em gestantes a partir da implantação do Programa de Vigilância da Toxoplasmose Adquirida e Congênita em municípios da região oeste do Paraná. Revista Brasileira de Ginecologia e Obstetrícia, Rio de Janeiro, v. 34, n. 2, p. 63-68, 2012.
BRANCO, L. A. Brucellosis and tuberculosis in cattle dairy of the Municipality of Umuarama, Paraná, Brazil. 2015. Dissertação (Mestrado em Ciência Animal) Universidade Paranaense, Umuarama.

BRASIL. Ministério da Saúde. Fundação Nacional da Saúde. Brasília. Manual de Leptospirose. Centro Nacional de Epidemiologia. Brasília: Editora MS - OS, $1995.98 \mathrm{p}$.

Instrução Normativa/SDA n. 2 a partir de 10.1.2001. Secretaria de Defesa Animal, Ministério da Agricultura, Pecuária e Abastecimento, Diário Oficial [da] União, Brasília, 4 jun. 2001, Seção 1, p. 26-31.

CAETANO, I. C. S. Soroepidemiologia da toxoplasmose em gestantes do município de Umuarama, Paraná, Brasil. 2013. Dissertação (Mestrado em Ciência Animal) - Universidade Paranaense, Umuarama.

CAMARGO, M. E. Introdução às técnicas de Imunofluorescência. Revista Brasileira de Patologia Clínica, Rio de Janeiro, v. 10, n. 3, p. 87-107, 1974.

CAPOBIANGO, J. D.; MITSUKA, B. R.; NAVARRO, I. T.; REZENDE, N. C. P.; BARBANTE, C. A. M.; RUIZ, L. M. F. M.; PAGLIARI, S.; INOUE, I. T.; REICHE, E. M. V. Congenital toxoplasmosis in a reference center of Paraná, Southern Brazil. Brazilian Journal of Infectious Diseases, Salvador, v. 18, n. 4, p. 364-371, 2014.

CARDOSO, S. C. T.; COSTA, L. M. C. A Brucelose no Brasil sob o enfoque da Saúde Pública. 2012. Monografia (Trabalho de Conclusão de Curso em Vigilância Sanitária) - Universidade Católica de Goiás, Goiânia.

CONFALONIERI, U. E.; DUTRA, F. R. L. S. Climate change and Vector-borne diseases in Latin America. In: AKHTAR, R.; MALIK, A. (Org.). Environmental degredation and human health. Climate change. Nova Deli: Springer Publisher, Book, 2014. v. 3, p. 315-324.

COUTO, J. C. D. F.; MELO, R. N.; RODRIGUES, M. V.; LEITE, J. M. Diagnóstico pré-natal e tratamento da toxoplasmose na gestação. Femina, Rio de Janeiro, v. 31, n. 1, p. 85-90, 2003.

DIAS, I. C. L. Prevenção de zoonoses ocupacionais em abatedouros de bovino. Revista Eletronica de Extensão da URI, Vivências, Santiago, v. 8, n. 15, p. 89-98, 2012.

DIAS, J. A.; MÜLLER, E. E.; DIAS, R. A.; FREITAS, J. C. D.; AMAKU, M.; FERREIRA, F.; FERREIRA NETO, J. S. Situação epidemiológica da brucelose bovina no Estado do Paraná. Arquivo Brasileiro de Medicina Veterinária e Zootecnia, Belo Horizonte, v. 61, n. 1, p. 66-76, 2009. 
DREER, M. K. P.; GONÇALVES, D. D.; CAETANO, I. C. S.; GERÔNIMO, E.; MENEGAS, P. H.; BERGO, D.; MORI, F. M. R. L.; BENITEZ, A.; FREITA, J. C.; EVERS, F.; NAVARRO, I. T.; MARTINS, L. A. Toxoplasmosis, leptospirosis and brucellosis in stray dogs housed at the shelter in Umuarama municipality, Paraná, Brazil. Journal of Venomous Animals and Toxins including Tropical Diseases, Botucatu, v. 19, n. 1, p. 1923, 2013.

DUBEY, J. P. Toxoplasmosis of animals and humans. Journal of Parasitology, Boca Raton, v. 96, n. 5, p. 940940, 2010.

DUBEY, J. P.; GAMBLE, H. R.; HILL, D.; SREEKUMAR, C.; ROMAND, S.; THUILLEZ, P. High prevalence of viable Toxoplasma gondii infection in market weight pigs from a farm in Massachusetts. Journal of Parasitology, Boca Raton, v. 88, n. 6, p. 12341238, 2002.

DUBEY, J. P.; LAGO, E. G.; GENNARI, S. M.; SU, C.; JONES, J. L. Toxoplasmosis in humans and animals in Brazil: high prevalence, high burden of disease, and epidemiology. Parasitology, Cambridge, v. 139, n. 11, p. 1375-1424, 2012.

ELLIS, W. A. Leptospirosis as a cause of reproductive failure. Veterinary clinics of North America: Journal of Small Animal Practice, Philadelphia, v. 10, n. 3, p. 463478, 1994.

EMPRESA BRASILEIRA DE PESQUISA AGROPECUÁRIA - EMBRAPA. Centro Nacional de Pesquisa de Solos. Sistema brasileiro de classificação dos solos. Brasília: Embrapa, 1999.

FAINE, S.; ADLER, B.; BOLIN, C.; PEROLAT, P. Leptospira and leptospirosis. 2. ed. Melbourne: Medisci, 1999. $272 \mathrm{p}$.

FRENKEL, J. K.; HASSANEIN, K. M.; HASSANEIN, R. S.; BROWN, E.; THULLIEZ, P.; QUINTERO-NUNEZ, R. Transmission of Toxoplasma gondii in Panama City, Panama: a five-year prospective cohort study of children, cats, rodents, birds, and soil. The American Journal of Tropical Medicine and Hygiene, Deerfield, v. 53, n. 5, p. 458-468, 1995.

GOLDSMITH, R. S. Infectious diseases: protozoal e helminthic. Current Medical Diagnosose Treatmente, Connecticut, v. 37, n. 1, p. 1294-1355, 1997.

GONÇALVES, D. D.; BENITEZ, A.; LOPES-MORI, F. M. R.; ALVES, L. A.; FREIRE, R. L.; NAVARRO, I. T.; SANTANA, M. A. Z.; SANTOS, T. C.; VIEIRA, M. L.; FREITAS, J. C. Zoonoses in humans from small rural properties in Jataizinho, Parana, Brazil. Journal of Microbiology, São Paulo, v. 44, n. 1, p. 125-131, 2013.
GONÇALVES, D. D.; TELES, O. S.; REIS, C. R.; LOPES-MORI, F. M. R.; FREIRE, R. L.; NAVARRO, I. T.; ALVES, L. A.; MULLER, E. E.; FREITAS, J. C. Soroepidemiologia e variáveis ocupacionais e ambientais relacionadas à leptospirose, brucelose e toxoplasmose em trabalhadores de frigorífico do Estado do Paraná, Brasil. Revista do Instituto de Medicina Tropical, São Paulo, v. 48, n. 3, p. 135-149, 2006.

GRESSLER, M. A.; SCHEID, R.; MARTINS, D.; FANFA, L.; KRUG, S. B. F. Leptospirose e exposição ocupacional; um estudo no município de Santa Cruz do Sul/RS. Revista de Epidemiologia e Controle de Infecção, Santa Cruz do Sul, v. 2, n. 2, p. 1- 4, 2012.

GUIMARÃeS, G. O. Programa nacional de controle $e$ erradicação de brucelose e tuberculose animal (PNCEBT): evolução no controle da Brucelose Bovina de 2001 a 2010. 2011. Monografia (Trabalho de Conclusão de Curso em Medicina Veterinária) - Universidade de Brasília, Brasília.

GUIMARÃES, M. C.; CÔRTES, J.; VAS CONCELLOS, S. A.; ITO, F. H. Epidemiologia e controle da leptospirose bovina. Importância do portador renal e do seu controle terapêutico. Comunicações Científicas da Faculdade de Medicina Veterinária e Zootecnia, São Paulo, v. 6, n. 1-4, p. 6-7, 1982.

LACERDA, L. M.; ALVES, L. M. C.; MATHIAS, L. A.; RODRIGUES, A. L. B.; ALMEIDA, F. M. Brucelose em trabalhadores de matadouros do Município de São Luís, MA, 1997. Higiene Alimentar, Mirandópolis, v. 14, n. 68/69, p. 62-65, 2000.

LAGE, A. P.; POESTER, F. P.; PAIXÃO, T. A.; SILVA, T. A.; XAVIER, M. N.; MINHARRO, S.; MIRANDA, K. L.; ALVES, C. M.; MOL, J. P. S.; SANTOS, R. L. Brucelose bovina: uma atualização. Revista Brasileira de Reprodução Animal, Belo Horizonte, v. 32, n. 3, p. 202212, 2008.

LANGONI, H.; VASCONCELOS, C. G. C.; NITSCHE, M. J. T.; OLBRICH, S. R. L. R.; CARVALHO, L. R.; SILVA, R. C. Fatores de risco para zoonoses em alunos do curso de medicina veterinária, residentes e pós-graduandos. Arquivos de Ciências Veterinárias e Zoologia, Umuarama, v. 12, n. 2, p. 115-121, 2009.

LIMA, V. Y. Inquérito soro-epidemiológico em acadêmicos de medicina veterinária de duas universidades do oeste do Paraná para a ocorrência de toxoplasmose e Leptospirose. 2008. Tese (Doutorado em Medicina Veterinária) - Faculdade de Medicina Veterinária e Zootecnia. Universidade Estadual Paulista, Botucatu. 
MENDONÇA, C. A. S. Pesquisa de soropositividade para diagnóstico de brucelose em grupos ocupacionais do município de Garanhuns-PE, submetidos às provas de soroaglutinação rápida (SAR) e antígeno tamponado acidificado (ATA). In: CONGRESSO DE INICIAÇAO CIENTIFICA DA UFRPE, 7., 1997, Recife. Resumo... Recife: UFRPE, 1997. p. 369.

OLIVEIRA, L. A. Soroepidemiologia da leptospirose e brucelose em ovinos e cães de propriedades rurais não tecnificadas da região noroeste do estado do Paraná. 2014. Dissertação (Mestrado em Ciência Animal) Universidade Paranaense, Umuarama.

PAULIN, L. M. S.; FERREIRA NETO, J. S. Brucelose em búfalos. Arquivos do Instituto Biológico, São Paulo, v. 75, n. 3, p. 389-401, 2008.

PELISSARI, D. M.; MAIA-ELKHOURY, A. N. S.; ARSKY, M. L. N. S.; NUNES, M. L. Revisão sistemática dos fatores associados à leptospirose no Brasil, 20002009. Epidemiologia e Serviços de Saúde, Brasília, v. 20, n. 4, p. 565-574, 2011.

POESTER, F.; FIGUEIREDO, V. C. F.; LOBO, J. R.; GONÇALVES, V. S. P.; LAGE, A. P.; ROXO, E.; MOTA, P. M. P. C.; MÜLLER, E. E.; FERREIRA NETO, J. S. Estudos de prevalência da brucelose bovina no âmbito do programa nacional de controle e erradicação de Brucelose e Tuberculose: introdução. Arquivo Brasileiro de Medicina Veterinária e Zootecnia, Belo Horizonte, v. 61, n. 1, p. 1-5, 2009.

RAMOS, T. R. R.; PINHEIRO JUNIOR, J. W.; MOURA SOBRINHO, P. A. D.; SANTANA, V. L. D. A.; GUERRA, N. R.; MELO, L. E. H. D.; MOTA, R. A. Epidemiological aspects of an infection by brucella abortus in risk occupational groups in the microregion of Araguaína, Tocantins. Brazilian Journal of Infectious Diseases, Salvador, v. 12, n. 2, p. 133-138, 2008.
RIBEIRO, M. G.; MOTTA, R. G.; ALMEIDA, C. A. S. Brucelose equina: aspectos da doença no Brasil. Revista Brasileira de Reprodução Animal, Belo Horizonte, v. 32, n. 2, p. 83-92, 2008.

RYU, E. Rapid microscopic agglutination test for Leptospira without non-specific reaction. Bulletin Office International Epizooties, Paris, v. 1-2, n. 73, p. 49-58, 1970.

SANTOS, H. P.; TEIXEIRA, W. C.; OLIVEIRA, M. M. M.; PEREIRA, H. M.; OLIVEIRA, R. A.; NEGREIRO, R. C.; SOARES FILHO, P. M.; SANTANA, S. S.; CASTRO, R. S. Brucelose bovina e humana diagnosticada em matadouro municipal de São Luís-MA, Brasil. Ciência Veterinária. Tropical, Recife. v. 10, n. 3, p. 86-94, 2007.

TEIXEIRA, A. C. P.; SOUZA, C. F. A.; SÁ, M. J. S. D.; RIBEIRO, R. M. P.; OLIVEIRA, A. D. L.; SOUZA, R. M. D. Brucelose-Zoonose controlada? Higiene Alimentar, Mirandópolis, v. 12, n. 54, p. 23-25, 1998.

TENTER, A. M.; HECKEROTH, A. R.; WEISS, L. M. Toxoplasma gondii: from animals to humans. International Journal for Parasitology, England, v. 30, n. 12, p. 1217-1258, 2000.

VICENTE, R. T.; MILLAR, P. R.; NICOLAU, J. L.; SOUZA, M. M. S. de; KLEIN, C. H.; SUDRÉ, A. P.; AMENDOEIRA, M. R. R. Soroepidemiologia da infecção toxoplásmica em alunos de medicina veterinária e de outros cursos de Universidades Públicas do Estado do Rio de Janeiro, Brasil. Revista de Patologia Tropical, Goiânia, v. 43, n. 3, p. 313-322, 2014. 
